IX междунар. науч. конф. 26-30 сентября 2011 г., г. Санкт-Петербург, Российская Федерация / отв. ред. И.И. Шамров. М.: Товарищество научных изданий КМК, 2011. С. 399-405.

11. Лавренко Е.М., Корчагин А.А. Полевая геоботаника. Т. ІІІ. М.; Л.: Изд-во «Наука», 1964. 530 с.

12. Воронов А.Г. Геоботаника. Издание второе испр. и доп. М.: Изд-во «Высшая школа», 1973. 384 с.

13. Черепанов С.К. Сосудистые растения России и сопредельных государств. СПб.: Изд-во «Мир и семья - 95», 1995. 992 с.

14. Fedtschenko B.A. Flore des iles du Commandeur. Cracovie, 1906.128 p.

15. Степанова К.Д., Белая Г.А. К флоре и растительности Командорских островов // Вопросы ботаники на Дальнем Востоке. Владивосток: ДВФ АН СCCР, 1969. С. 141-165.

16. Пономарева Е.О., Яницкая Т.О. Растительный покров Командорских островов // Природные ресур- сы Командорских остров: запасы состояние, вопросы охраны и использования / отв. ред. В.Е. Соколов. М.: МГУ, 1991. С. 59-98.

17. Hulten E. Flora of Kamtchatka and adjacent islands. Stockholm, 1927. Band. 5. 216 p.

18. Hulten E. Flora of the Aleutian Islands and westernmost Alaska Penunsula with notes on the flora of the Commander Islands. 2 nd. ed. Weinheim, 1960. 400 p.

19. Крестов П.В. Растительный покров Командорских островов // Ботанический журнал. 2004. Т. 89, № 11. С. 1740-1762.

20. Могилева А.В. Заметки к флоре Командорских островов // Экология родного края: проблемы и пути их решения: мат-лы XIV всерос. науч.-практ. конф. с междунар. уч. 16-18 апреля 2019 г., г. Киров, Российская Федерация / отв. ред. Т.Я. Ашихмина. Киров: ВятГУ, 2019. С. 285-288.

\title{
CURRENT STATUS OF CYPRIPEDIUM MACRANTHON SW. (ORCHIDACEAE) COENOPOPULATION ON BERING ISLANDS (KOMANDORSKY RESERVE)
}

(C) 2019

Mogileva Anzhelika Vasilyevna, junior researcher of Ecology and Plant Resources Department Professor Zhitkov Russian Research Institute of Game Management and Fur Farming (Kirov, Russian Federation)

Lavrentyev Mikhail Vasilyevich, candidate of biological sciences, leading engineer, assistant of Chair of Botany and Ecology

Petrova Nadezhda Andreevna, head of Flora and Vegetation Department at Education and Research Centre «Botanic Garden» Saratov State University (Saratov, Russian Federation)

Abstract. The paper presents the results of Cypripedium macranthon Sw. monitoring on Bering Island (Kamchatka Krai) in 2012-2018. Cypripedium macranthon Sw is a rare Orchidaceae species enlisted in several regional Red Books and the Red Book of the Russian Federation. The species on Bering Island inhabits its north-eastern range border and is protected in Komandorsky State Biosphere Nature Reserve. 7 coenopoulations of C. macranthon are found on the island. The studied coenopopulation inhabits the polydominant mixed-herbs-gramineous meadow on coastal sandy dunes. The coenopopulation occupies 4,0 ha and consists of separate loci. The vital state of the plants was defined as normal (3 points). Adult vegetative and generative individuals prevail in the coenopopulation. According to our data the number of shoots was 8 to 16 individuals per sq. m. The average number of generative shoots in 2013,2017 and 2018 was 9, 10 and 1,4 correspondingly. The maximum generativity index of 81,8\% was marked in 2013 due to favorable conditions of the vegetative season. The quantitative data from different periods allow to assume that $C$. macranthon coenopopulation's state is stable which if determined by the population dynamics and proportion of generative shoots.

Keywords: Cypripedium macranthon Sw; Orchidaceae; coenopopulation; test area; Red Book; monitoring; rare species; shoots dynamics; generativity dynamics; range border; coastal dunes; protected area; Komandorsky reserve; Kamchatka Krai; Commander Islands; Bering Island.

\section{РАСПРЕДЕЛЕНИЕ ТЯЖЁЛЫХ МЕТАЛЛОВ ПО ПРОФИЛЮ ПОЧВ ВЫРАБОТАННОГО ТОРФЯНИКА}

\author{
Новосёлова Елена Сергеевна, преподаватель кафедры экологии и зоологии \\ Шихова Людмила Николаевна, доктор сельскохозяйственных наук, \\ профессор кафедры экологии и зоологии
}

Вятская государственная сельскохозяйственная академия (г. Киров, Российская Федерация)

Лисицын Евгений Михайлович, доктор биологических наук, профессор кафедры экологии и зоологии; заведующий отделом эдафической устойчивости растений

Вятская государственная сельскохозяйственная академия (2. Киров, Российская Федерация); Федеральный аграрный научный иеентр Северо-Востока имени Н.В. Рудницкого (г. Киров, Российская Федерация)

Аннотация. В статье представлены результаты исследования содержания валовых и подвижных соединений тяжелых металлов (свинца, кадмия, меди и цинка) в профиле почв выработанного торфяника Зенгин- 
ский, расположенного в центральной части Кировской области. В результате проведенных исследований выявлено, что содержание элементов в разных слоях торфа контрольного участка (цинк - до 2,60; медь - до 0,90; свинец - до 5,60; кадмий - до 0,59 мг/кг почвы) не превышает уровня их предельно допустимых концентраций и фонового содержания в почвах Кировской области. Для неосвоенного участка отмечено повышенное содержание валовых и подвижных соединений изученных металлов в верхних слоях, что может быть обусловлено биогенным накоплением данных элементов растениями. Профили освоенных почв (осушенные участки) характеризуются значительными колебаниями содержания элементов как в разных профилях, так и в разных горизонтах одного и того же профиля. Здесь максимальные содержания элементов в отдельных слоях значительно выше контрольных (цинк - до 126,0; медь - до 34,0; свинец - до 17,0; кадмий - до 1,2 мг/кг почвы). Хозяйственное использование ведет к активной минерализации верхней части оставшейся торфяной толщи. В результате этих процессов нарушается стабильность биогеохимических циклов отдельных элементов. При этом полученные результаты позволяют рассматривать почвы контрольных участков в качестве индикаторов состояния окружающей природной среды. Хорошая сохранность торфяных отложений дает возможность изучать процессы накопления и миграции химических элементов.

Ключевые слова: торфяная залежь; низинное болото; болото переходного типа; осушение болот; аккумуляция металлов; цинк; медь; свинец; кадмий; почвенный профиль; Зенгинский торфомассив; Кировская область; зональный тип почвообразования; предельно допустимые концентрации; региональный фоновый уровень.

\section{Введение}

Болотные биогеоценозы являются важной составной частью природных комплексов бореальной зоны. Болота участвуют в регулировании климата и водообмена территории. Образующееся органическое вещество запасается на длительные периоды, снижая при этом выделение углекислого газа обратно в атмосферу [1, с. 3-8]. В процессе формирования болота происходит накопление и консервация в торфе различных химических элементов, в том числе и тяжелых металлов, таких как $\mathrm{Pb}, \mathrm{Cu}, \mathrm{Zn} \mathrm{и} \mathrm{Cd}[2$, c. $496 ; 3$, с. 3]. Из-за специфических свойств торфа (наличие большого числа кислых функциональных групп в составе органического вещества [4, с. 15] болотные системы являются огромными естественными аккумуляторами, которые способны накапливать и сохранять многие тысячелетия различные химические элементы и вещества $[5$, с. 9-10].

Осушение и добыча торфа ведут к разрушению и резкому изменению условий существования болот [6, с. 42], к трансформации болотных почв в направлении зонального типа почвообразования. Судьба тяжелых металлов после освоения болот не ясна. С одной стороны, активная минерализация органического вещества в результате осушения должна способствовать повышению подвижности и миграционной способности большинства элементов [7, с. 9-10]. С другой стороны, изменение гидрологических, окислительно-восстановительных, кислотно-щелочных и других режимов приводит к появлению геохимических барьеров, на которых возможно осаждение ТМ. Поэтому содержание и поведение химических элементов в болотных почвах будет зависеть от конкретной геохимической ситуации.

Анализ литературных данных за последние 2025 лет показал, что, хотя в глобальном масштабе важность болотных экосистем не вызывает сомнения, детальные экологические исследования в большинстве случаев проводятся на верховых болотах (ombrotrophic systems = bogs), а низинные болота (minerotrophic mires $=$ fens) и болота переходного типа изучаются гораздо реже. Основной причиной этого является сложность факторов, влияющих на формирование торфа низинных болот по сравнению с верховыми болотами [8, с. 3].

Цель данной работы - выявить закономерности распределения ионов тяжелых металлов в почвенном компоненте биогеоценозов болот низинного и пере- ходного типов в связи с их осушением и дальнейшим хозяйственным использованием.

\section{Материалы и методики исследования}

Кировская область занимает восточную часть Русской равнины. По имеющимся данным, в 70-е годы XX века на территории области было выявлено и разведано 1734 торфяных месторождения, а к концу 90-х годов их выявлено и описано 1858. Площадь торфяников области составляет почти 510 тыс. га, из которых $60 \%$ занимают низинные болота [9, с. 5]. Наиболее крупные болотные массивы осушены и освоены. Наибольшее распространение болота получили на широких плоских, сглаженных и пониженных водораздельных пространствах северной, северо-восточной и центральной частях области, на низинных участках речных пойм и террас [10, с. 7]. Особенностью болот Кировской области является то, что подстилающими породами в южной части области являются карбонатные породы палеозойского возраста, а в северной - бескарбонатные отложения московского и днепровского оледенений.

Зенгинское болото расположено в Оричевском районе Кировской области на первой надпойменной террасе реки Вятка. Подстилающими торф породами являются аллювиальные и древнеаллювиальные отложения легкого гранулометрического состава, которые, в свою очередь, на разной глубине подстилаются карбонатными суглинками и карбонатами $[10$, c. 56-62]. Район приурочен к низменности - древнему руслу ледниковых потоков. Преобладающим типом торфообразования является низинный, но в центральных, наиболее глубоко залегающих частях месторождения встречаются смешанные и верховые участки. Площадь болота составляет 6000 га, максимальная мощность торфяного слоя 5,0 м, средняя 1,71 м. Торфомассив разрабатывался с 1949 года, в 1983-1984 гг. добыча торфа прекращена. Контрольный участок на торфомассиве был выбран в сосняке багульниково-зеленомошном на слабоосушенной неосвоенной части болота с мощностью торфяной залежи около 1,5-2,0 м. Ключевые участки были заложены на территориях с естественными луговыми и лесными фитоценозами, которые сформировались после осушения и сработки торфа и на территориях, вовлеченные в хозяйственную деятельность. Последние заняты посадками Pinus silvestris L. и Picea abies (L.) H. Karst. разного возраста от 9-11 до 3540 лет, а также используются под посев кормовых 
культур. На данных участках мощность остаточного слоя торфа составила от 1,3-1,5 м до 0,5 м и меньше. Географические точки отбора проб имеют следующие координаты: контрольная точка 58 $31^{\prime} 07,6^{\prime \prime}$ с.ш., $48^{\circ} 59^{\prime} 04,0^{\prime \prime}$ в.д.; освоенные участки - 1) 58³0'09, $5^{\prime \prime}$ с.ш., $48^{\circ} 59^{\prime} 03,1^{\prime \prime}$ в.д.; 2) $58^{\circ} 31^{\prime} 18,6^{\prime \prime}$ с.ш., $49^{\circ} 00^{\prime} 47,3^{\prime \prime}$ в.д.; 3) $58^{\circ} 30^{\prime} 40,2^{\prime \prime}$ с.ш., 48 59'34,7" в.д.

В течение трех полевых сезонов на каждом ключевом участке были заложены по 4 пробные площади, на которых проведено геоботаническое описание [11, с. 33-37], в соответствии с требованиями ГОСТ 17.4.3.01-83 заложены почвенные разрезы и отобраны пробы почв и торфа по слоям. Слои торфа разделялись визуально по различиям в ботаническом составе толщи. Согласно общепринятым методикам, в полевых условиях определяли степень разложения торфа и ботанический состав [12, с. 13-14, 20-29]. В последующем в лабораторных условиях при более детальном изучении ботанический состав уточняли [12, с. 30-32; 13, с. 6-51]. Аналитическую обработку собранного материала проводили в лаборатории кафедры экологии и зоологии Вятской государственной сельскохозяйственной академии и лаборатории эдафической устойчивости растений ФАНЦ Северо-Востока им. Н.В. Рудницкого (г. Киров). Содержание валовых и подвижных форм цинка, меди, свинца и кадмия определяли методом инверсионной вольтамперометрии на анализаторе ТА-4 разработки Томского политехнического института (Российская Федерация) согласно методическим разработкам производителя.

На рисунках приведены средние показатели содержания тяжелых металлов (контрольная точка -3 года $\times 5$ повторностей; для остальной части -3 года $\times 3$ участка $\times 5$ повторностей) с указание ошибки средней арифметической.

\section{Результаты исследования и их обсуждение}

Проведенные исследования показали, что содержание исследуемых химических элементов незначительно и не превышает средних и фоновых значений, характерных для различных типов почв области. Из литературных источников и данных наших предыдущих исследований известно, что содержание исследуемых химических элементов в болотных почвах не превышает фоновых концентраций в торфяных почвах Кировской области (табл. 1).

Однако в процессе трансформации болотных почв в направлении зонального типа почвообразования происходит активная минерализация органической массы и вовлечение в биогеохимический круговорот законсервированных химических элементов.

Для оценки того, загрязнен ли торф конкретным элементом, необходимо сравнить его содержание в торфе со средним содержание в земной коре (индекс экологического риска RI). Согласно Håkanson [18, c. 993], при величине показателя RI ниже единицы можно говорить о низкой степени загрязнения, при величине 1-3 - умеренном, 3-6 - сильном и при превышении 6 - очень сильном загрязнении. Как видно из приведенных в таблице данных, в среднем для Кировской области содержание исследуемых элементов в торфах соответствует низкой степени загрязнения, хотя в наиболее распространенной в области дерново-подзолистой почве отмечается умеренное загрязнение свинцом и сильное/очень сильное загрязнение кадмием.

На контрольном участке (слабо осушенной неосвоенной части) торфомассива Зенгинский отмечено наименьшее содержание элементов в профиле по сравнению с другими обследованными территориями (рис. 1). Содержание валовых форм цинка в разных слоях почвенного профиля варьирует от 0,16 до 2,60 мг/кг, подвижных - от следовых значений до 1,60 мг/кг. Содержание меди в торфе изменяется от следовых значений до 0,90 мг/кг для валовых и до 0,12 мг/кг для подвижных форм.

Отмечено повышенное содержание и валовых, и подвижных соединений обоих элементов в верхних слоях, что совпадает с литературными данными [3, с. $3 ; 19$, с. 296]. Повышение содержания этих элементов в верхних слоях обусловлено биогенным накоплением данных элементов растениями [20, c. 112]. Концентрация цинка и меди в нижележащих слоях снижается до следовых значений.

Содержание валового свинц̧а в почвах контрольного участка колеблется от 0,37 до 5,60 мг/кг, подвижных форм - от следовых до 2,90 мг/кг (рис. 1). Максимальное содержание элемента в почвенном профиле характерно для верхних слоев торфа (0-20 см).

Содержание кадмия в пробах торфа контрольного участка не превышает фоновых значений. Отмечается низкое содержание элемента в слоях торфа (от следовых значений до 0,59 мг/кг валовых и до 0,038 мг/кг подвижных).

Кадмий и свинец не являются жизненно важными элементами для растений [21, с. 295, 345]. Несмотря на высокую фитотоксичность, некоторые количества элементов накапливаются в фитомассе. Накопление и свинца, и кадмия в самых верхних слоях торфа может быть обусловлено как биогенным накоплением этих элементов, так и атмосферным антропогенным загрязнением. По мнению O. Nikodemus et al. [22, с. 526], в последние десятилетия произошло повышенное накопление свинца в торфяных залежах на западе Латвии в связи с дальними воздушными перемещениями поллютанта из Европы. Как считает E.E. Veretennikova [23, с. 106], в настоящее время в торфяниках, удаленных от индустриальных источников свинца, расположенных в регионах с низким уровнем экономической активности, концентрация свинца и скорость его накопления в основном определяется глобальным уровнем атмосферного загрязнения, типичным для начала индустриальной эпохи.

таблица 1 - Пределы содержания валовых форм исследуемых элементов в почвах Кировской области, мг/кг

\begin{tabular}{|c|c|c|c|c|}
\hline \multirow{2}{*}{ Металл } & \multirow{2}{*}{$\begin{array}{c}\text { дерново-подзолистая } \\
\text { почва }^{1} \\
\end{array}$} & \multicolumn{2}{|c|}{ тор $\phi^{2}$} & \multirow{2}{*}{$\begin{array}{c}\text { Среднее содержание в земной } \\
\text { коре }^{3}\end{array}$} \\
\hline & & низинного типа & переходного типа & \\
\hline $\mathrm{Zn}$ & $30,00-70,00$ & $8,50-56,10$ & $3,60-30,60$ & 70,00 \\
\hline $\mathrm{Cu}$ & $45,00-50,00$ & \multicolumn{2}{|c|}{$2,00-6,00$} & 60,00 \\
\hline $\mathrm{Pb}$ & $5,00-43,00$ & - & - & 14,00 \\
\hline $\mathrm{Cd}$ & $0,70-1,03$ & - & - & 0,15 \\
\hline
\end{tabular}

Примечание. ${ }^{1}-$ по $[14$, с. $78,94,109,124 ; 15] ;{ }^{2}$ - по [16, с. $\left.79-81\right] ;{ }^{3}$ - по [17, с. 2215]. 
Новосёлова Е.С., Шихова Л.Н., Лисицын Е.М.
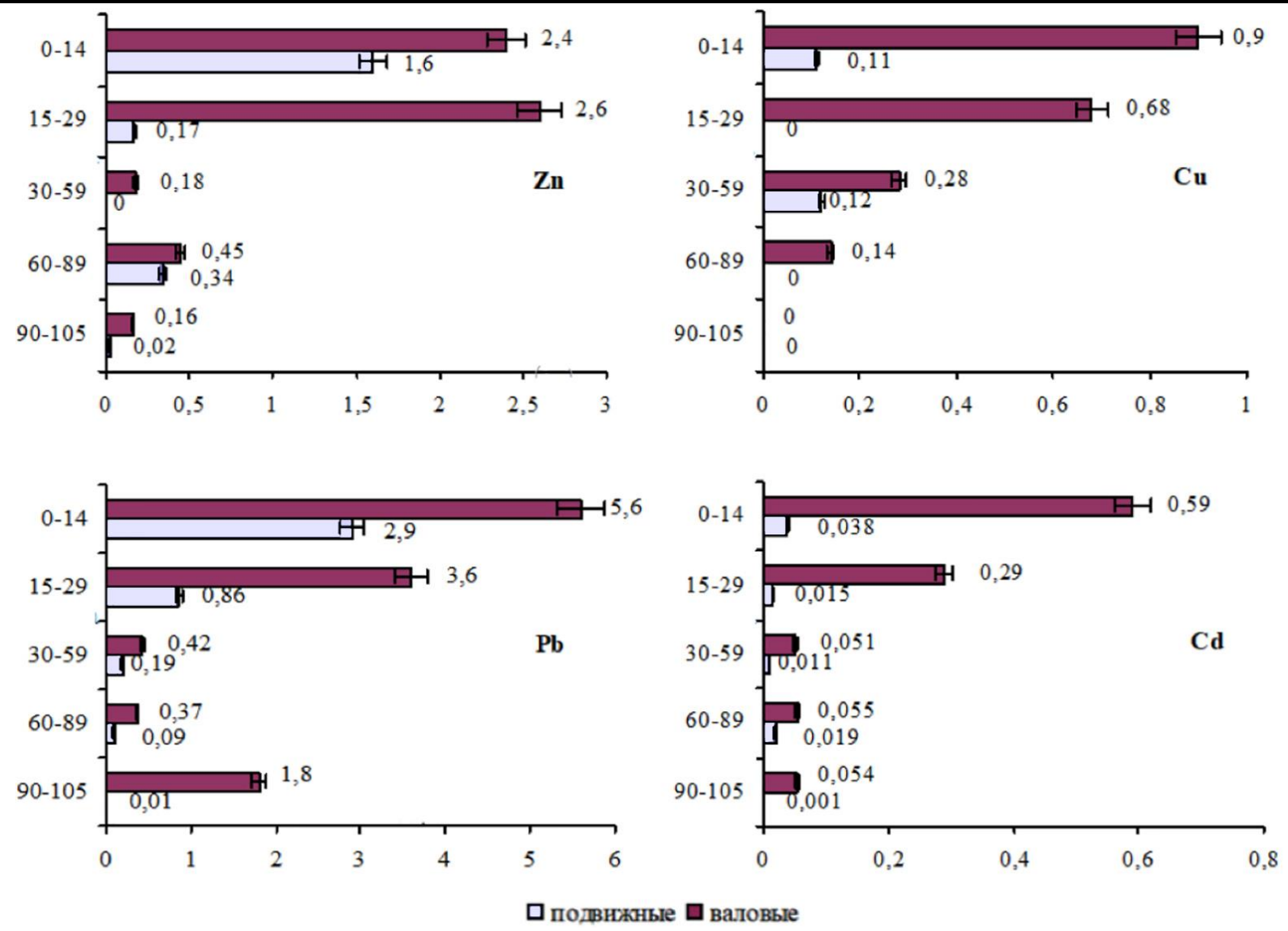

Рисунок 1 - Среднее содержание ТМ в торфе слабо осушенного неосвоенного (контрольного) участка торфомассива Зенгинский.

Приведены средние показатели содержания тяжелых металлов (3 года $\times 5$ повторностей) с указанием ошибки средней арифметической. По оси ординат «глубина, см», по оси абсцисс «содержание элементов, мг/кг»

По данным Л.П. Гашковой, Е.С. Ивановой [24, c. 733], на участках, где проводилась добыча торфа, растения активнее всего аккумулируют именно ионы кадмия; на участках болот с высокой степенью нарушенности коэффициент биологического поглощения таких элементов, как цинк, кадмий, свинец и медь, значимо выше, чем на ненарушенных участках.

В целом, невысокое содержание тяжелых металлов в торфяных почвах контрольного участка обусловлено особенностями формирования болота, а также низким содержанием элементов в песчаных породах, подстилающих торфяную залежь. Для всех четырех элементов четко прослеживается биогенноаккумулятивное накопление в верхних слоях торфяной залежи. Нельзя исключать также и привнесение элементов с атмосферным переносом при техногенном загрязнении атмосферы. Однако в данном случае техногенное загрязнение болотных массивов как таковое не рассматривается. Считается, что данные территории подвержены минимальному воздействию со стороны хозяйственной деятельности человека.

Освоение торфомассива привело к изменению содержания и перераспределению химических элементов во вновь формирующихся почвенных профилях. Отмечены более резкие колебания содержания элементов по глубине во всех исследованных профилях (рис. 2) по сравнению с почвами неосвоенной части массива (рис. 1), что согласуется с литературными данными, касающимися анализа содержания тяжелых металлов в нарушенных торфяниках [25, с. 23].

Содержание валовых форм меди варьирует от следовых значений до 34,00 мг/кг; цинка в остаточ- ных слоях торфа - от следовых значений до 126,00 мг/кг, в нижней минеральной части почвенного профиля - до 40,00 мг/кг.

Повышенные (относительно контрольного участка) концентрации меди и цинка выявлены в верхних горизонтах некоторых профилей на участках с развитым растительным покровом. Цинк и медь являются биогенными элементами, активно поглощаются и накапливаются растениями.

Валовое содержание свинца в профилях варьирует от следовых значений до 17,00 мг/кг, содержание подвижных форм свинца не превышает 2,30 мг/кг.

Содержание валовых соединений кадмия в слоях обследованных профилей в среднем не превышает 1,00-1,20 мг/кг. При этом на некоторых участках выявлены повышенные концентрации элемента в отдельных слоях торфяной залежи, которые достигают 4,41-8,60 мг/кг. Содержание подвижных форм кадмия в профиле выработанных торфяных почв характеризуется как следовое.

В отличие от цинка и меди, кадмий и свинец не относятся к биогенным элементам. Однако в некоторых профилях выявлено повышение содержания элементов именно в верхней части почвенного профиля. С одной стороны, это может быть связано с биогенным накоплением элемента живыми организмами и активной минерализацией верхних слоев торфа. Но также это может быть обусловлено наличием антропогенных источников поступления кадмия в окружающую среду в результате осушения и работ по добыче торфа на данной территории. 

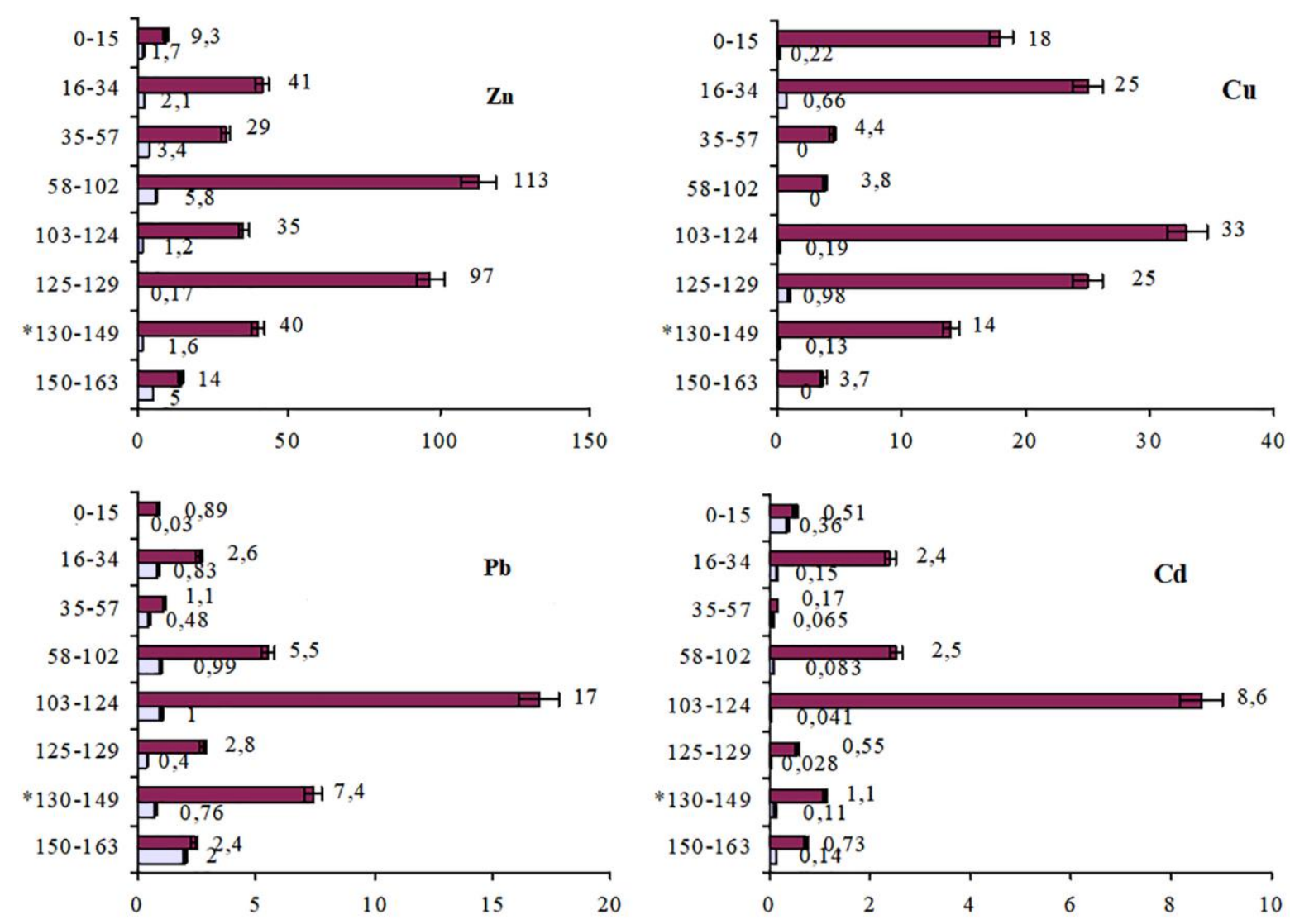

\section{口 подвнжные $\square$ валовые}

Рисунок 2 - Среднее содержание ТМ в профиле торфомассива Зенгинский. Приведены средние показатели содержания тяжелых металлов (3 года $\times 5$ повторностей)

с указанием ошибки средней арифметической. По оси ординат - глубина, см, по оси абсцисс содержание элементов, мг/кг. * - переход от торфяной залежи к минеральным подстилающим породам

Колебания содержания тяжелых металлов в толще торфа, очевидно, обусловлены разными причинами. Одной из причин является различный ботанический состав торфяных слоев $[4$, с. $16 ; 26$, с. $105-$ 107]. Известно, что древесно-сфагновый торф больше, чем другие концентрирует молибден; шейхцериево-сфагновый - цинк; древесно-осоковый - марганец и кобальт [27, с. 207]. По мнению Е.Н. Гузовой, низинные торфы по способности накапливать химические элементы можно построить в следующий ряд по убыванию их содержания: древесный - древесноосоковый - осоково-гипновый - осоковый [28, с. 253].

В некоторых случаях колебания содержания элемента обусловлены сменой торфяной залежи на минеральные подстилающие породы. Переходные (контактные) горизонты уплотнены и имеют примеси илистых и глинистых частиц в составе торфа. На границе между торфяной толщей и минеральными слоями происходит резкая смена почвенных условий [27, с. 243-245]. Переходные горизонты, как правило, задерживают влагу, а вместе с ней и химические элементы, просачивающиеся из верхних слоев. В результате этого в таких горизонтах может отмечаться повышение содержания элементов.

\section{Выводы}

Таким образом, в ходе проведенных исследований выявлено, что содержание свинца, кадмия, цинка и меди в слоях торфа выработанного торфяника Зенгинский центральной части Кировской области незначительно и не превышает предельно допусти- мых концентраций и фонового содержания в почвах Кировской области.

Профили освоенных торфяников характеризуются значительными колебаниями содержания тяжелых металлов как в разных профилях, так и в разных горизонтах одного и того же профиля. Данные факты говорят о происходящей в освоенных и осушенных почвах перестройке почвенных процессов и режимов.

Осушение болот и их дальнейшее хозяйственное освоение способствуют преобразованию этих природных комплексов. Хозяйственное использование ведет к активной минерализации верхней части оставшейся торфяной толщи. В результате этих процессов нарушается стабильность биогеохимических циклов отдельных элементов. При этом полученные результаты позволяют рассматривать эти «природные архивы» в качестве индикаторов состояния окружающей природной среды. Хорошая сохранность торфяных отложений дает возможность изучать процессы накопления и миграции химических элементов.

\section{Список литературы:}

1. Beilman D.W., MacDonald G.M., Smith L.C., Reimer P.J. Carbon accumulation in peatlands of West Siberia over the last 2000 years // Global Biogeochemical Cycles. 2009. Vol. 23 (1). GB1012. DOI: 10.1029/ 2007 GB003112.

2. Mezhibor A., Arbuzov S., Rikhvanov L., GauthierLafaye F. History of the Pollution in Tomsk Region (Siberia, Russia) According to the Study of High-Moor Peat Formations // International Journal of Geosciences. 2011. Vol. 2. P. 493-501. DOI: 10.4236/ijg.2011.24052. 
3. Borgulat J., Mętrak M., Staszewski T., Wiłkomirski B., Suska-Malawska M. Heavy Metals Accumulation in Soil and Plants of Polish Peat Bogs // Polish Journal of Environmental Studies. 2018. Vol. 27 (2). P. 537-544. DOI: $10.15244 /$ pjoes/75823.

4. Krumins J., Robalds A. Biosorption of Metallic Elements onto Fen Peat // Environmental and Climate Technologies. 2014. Vol. 14. P. 12-17. DOI: 10.1515/ rtuect-2014-0008.

5. Forel B., Monna F., Petit C., Bruguier O., Losno R., Fluck P., Begeot C., Richard H., Bichet V., Chateau C. Historical mining and smelting in the Vosges Mountains (France) recorded in two ombrotrophic peat bogs // Journal of Geochemical Exploration. 2010. Vol. 107. P. 9-20. DOI: 10.1016/j.gexplo.2010.05.004.

6. Серебренникова О.В., Стрельникова Е.Б., Прейс Ю.И., Аверина Н.Г., Козел Н.В., Бамбалов Н.Н., Ракович В.А. Состав экстрактивных веществ торфов осушенных и ненарушенных верховых болот Беларуси и Западной Сибири // Известия Томского политехнического университета. Химия и химические технологии. 2014. Т. 325, № 3. С. 31-45.

7. Kõlli R., Asi E., Apuhtin V., Kauer K., Szajdak L.W. Chemical properties of surface peat on forest land in Estonia // Mires and Peat. 2010. Vol. 6. Article 06. P. 1-12.

8. Givelet N., Le Roux G., Cheburkin A., Chen B., Frank J., Goodsite M., Kempter H., Krachler M., Noernberg T., Rausch N., Rheinberger S., Roos-Barraclough F., Sapkota A., Scholz C., Shotyk W. Suggested protocol for collecting, handling and preparing peat cores and peat samples for physical, chemical, mineralogical and isotopic analyses // Journal of Environmental Monitoring. 2004. Vol. 6. P. 481-492. DOI: 10.1039/b401601g.

9. Долголетнее культурное пастбище на осушенной торфяной почве / В.М. Косолапов, А.Н. Уланов, Е.Л. Журавлева, Х.Х. Шельменкина, О.Г. Мокрушина, А.В. Смирнова, В.Г. Косолапова, В.Н. Ковшова, Ю.В. Помаскина. Киров: ООО ВЕСИ, 2015. 124 с.

10. Зверков Ю.В. Вторая жизнь торфяников. Киров: Волго-Вятское кн. изд-во, 1982. 80 с.

11. Методы изучения лесных сообществ / Е.Н. Андреева, И.Ю. Баккал, В.В. Горшков, Ш.В. Лянгузова и др. СПб.: НИИ Химии СПбГУ, 2002. 240 с.

12. Куликова Г.Г. Краткое пособие к ботаническому анализу торфа. М.: Изд-во Московского университета, 1974. 95 с.

13. Домбровская А.В., Коренева М.М., Тюремнов С.Н. Атлас растительных остатков, встречаемых в торфе. М.: Гос. энергет. изд-во, 1959. 137 с.

14. Шихова Л.Н., Егошина Т.Л. Тяжелые металлы в почвах и растениях таежной зоны Северо-Востока
Европейской России. Киров: Зональный НИИСХ Северо-Востока, 2004. 264 с.

15. Эколого-геохимическая карта почв Кировской области. СПб.: ВСЕГЕИ. 1996.

16. Уланов А.Н. Торфяные и выработанные почвы южной тайги евро-северо-востока России. Киров: ОАО «Дом печати - Вятка», 2005. 320 с.

17. CRC Handbook of Chemistry and Physics, 84th / editor-in-chief: D.R. Lide (National Institute of Standards and Technology) CRC Press/Taylor \& Francis Group: Boca Raton, FL. 2004. 2475 p.

18. Håkanson L. An Ecological Risk Index for Aquatic Pollution Control: A Sedimentological Approach // Water Research. 1980. Vol. 14. P. 975-1001.

19. Syrovetnik K., Neretnieks I., Malmström M.E. Accumulation of heavy metals in the Oostriku peat bog, Estonia: Determination of binding processes by means of sequential leaching // Environmental pollution. 2007. 147 (1), P. 291-300. DOI: 10.1016/j.envpol.2005.10.048.

20. Завгородняя Р.Е. Микроэлементный состав некоторых торфяных почв Карелии разных сроков освоения // Ученые записки Петрозаводского государственного университета. 2015. № 8 (153). С. 111-114.

21. Kabata-Pendias A. Trace elements in soils and plants. 4th Edition. CRC Press: Boca Raton London, New York, Washington, 2010. 548 p.

22. Nikodemus O., Brumelis G., Tabors G., Lapina L., Pope S. Monitoring of air pollution in Latvia between 1990 and 2000 using moss // Journal of Atmospheric Chemistry. 2004. Vol. 49. P. 521-531. DOI: 10.1007/s 10874-004-1263-2.

23. Veretennikova E.E. Lead in the natural peat cores of ridge-hollow complex in the taiga zone of West Siberia // Ecological Engineering. 2015. Vol. 80. P. 100-107. DOI: 10.1016/j.ecoleng.2015.02.001.

24. Гашкова Л.П., Иванова Е.С. Аккумуляция тяжелых металлов в растениях-доминантах антропогенно нарушенных участков болот на территории Томской области // Известия Самарского научного центра РАН. 2014. Т. 16, № 1 (3). С. 732-735.

25. Fiałkiewicz-Kozieł B., Smieja-Król B., Palowski B. Heavy metal accumulation in two peat bogs from southern Poland // Studia Quaternaria. 2011. Vol. 28. P. 17-24.

26. Rydin H., Jeglum J.K. The biology of peatland. 2nd edition. Biology of habitats. Oxford: Oxford University Press, 2013. 382 p.

27. Тюремнов С.Н. Торфяные месторождения. М.: Недра, 1976. 488 с.

28. Гузона Е.Н. Химический состав торфов // Ландшафты болот Томской области / под ред. Н.С. Евсеевой. Томск: Изд-во НТЛ, 2012. С. 248-255.

\title{
DISTRIBUTION OF HEAVY METALS IN CUTOVER PEAT BOG SOILS
}

(C) 2019

\author{
Novosyolova Elena Sergeevna, lecturer of Ecology and Zoology Department \\ Shikhova Lyudmila Nikolaevna, doctor of agricultural sciences, professor of Ecology and Zoology Department \\ Vyatka State Agricultural Academy (Kirov, Russian Federation) \\ Lisitsin Evgeny Mikhailovich, doctor of biological sciences, professor of Ecology and Zoology Department; \\ head of Plant Edaphic Resistance Department \\ Vyatka State Agricultural Academy (Kirov, Russian Federation); \\ Federal Agricultural Research Center of the North-East named N.V. Rudnitsky (Kirov, Russian Federation)
}

Abstract. The paper contains the research results on content of total and mobile heavy metals compounds (lead, cadmium, copper, and zinc) in soils of the cutover peat bog Zenginsky located in the central part of the Kirov Region. As a result of the conducted researches it is revealed that the content of elements in different peat layers in con- 

(zinc - up to 2,60; copper - up to 0,90; lead - up to 5,60; cadmium - up to $0,59 \mathrm{mg} / \mathrm{kg}$ of soil) does not exceed the level of their maximum-permissible concentration and background contents in soils of the Kirov Region. For the undeveloped site the increased content of total and mobile compounds of the studied metals in the top layers is noted; it can be caused by biogenous accumulation of these elements by plants. The developed soils (the drained sites) are characterized by considerable fluctuations of elements content both in different profiles, and in the different layers of the same profile. Here the maximum content of elements in separate layers is much higher than control (zinc - up to 126,0; copper - up to 34,0 ; lead - up to 17,0; cadmium - up to $1,2 \mathrm{mg} / \mathrm{kg}$ of soil). Economic use of the peat bogs leads to an active mineralization of the top part of the remained peat mass. As a result of these processes stability of biogeochemical cycles of separate elements is broken. At the same time, the received data allow to consider soils of control sites as indicators of surrounding environment condition. The good safety of peat deposits gives the opportunity to study processes of accumulation and migration of chemical elements.

Keywords: peat deposit; fen; transition-type bog; drainage of bog; accumulation of metals; zinc; copper; lead; cadmium; soil profile; Zenginsky peatbog; Kirov Region; zone type of soil formation; maximum-permissible concentration; regional background level.

$* * *$

УДК 574.22:574.23:57.044

DOI 10.24411/2309-4370-2019-13111

Статья поступила в редакцию 15.06.2019

\section{МОДЕЛЬНОЕ БИОТЕСТИРОВАНИЕ ВЛИЯНИЯ СОЛЕЙ ТЯЖЁЛЫХ МЕТАЛЛОВ НА ЖИЗНЕСПОСОБНОСТЬ КЛУБЕНЬКОВЫХ БАКТЕРИЙ RHIZOBIUM MELILOTI}

(C) 2019

Ознобихина Анастасия Олеговна, аспирант, ассистент кафедры техносферной безопасности Тюменский индустриальный университет (2. Тюмень, Российская Федераџия)

Першаков Анатолий Юрьевич, аспирант кафедры

технологии производства, хранения и переработки продукции растениеводства

Ерёмин Дмитрий Иванович, доктор биологических наук, профессор кафедры почвоведения и агрохимии

Государственный аграрный университет Северного Зауралья (г. Тюмень, Российская Федераџия)

Аннотащия. Исследование заключается в проведении биотестирования модельно загрязненной тяжелыми металлами среды с использованием в качестве тест-объекта микроорганизмов Rhizobium meliloti. В лабораторных условиях установлена реакция жизнеспособности клубеньковых бактерий донника и люцерны к свинцу, кадмию, меди и цинку. Действие изучаемых металлов на численность колоний зависит от концентрации химического элемента, физиологического действия микроэлемента, биологических особенностей используемых штаммов. Проведенными исследованиями определена прямая зависимость снижения роста численности колоний ризобий донника и люцерны с возрастанием концентрации солей тяжелых металлов. Ингибирование числа колоний имело выраженную закономерность при загрязнении среды свинцом, медью и кадмием в концентрации 0,3\%, при последующем увеличении наблюдалась полная гибель микроорганизмов. С внесением в питательную среду цинка в малых концентрациях прослеживалась положительная тенденция устойчивости бактерий донника и люцерны. Так, при 0,01-0,1\% содержании соли цинка число выросших колоний находилось выше уровня контроля и составило 714-987 шт. при контрольном значении - 578 шт. В среде с концентрацией $0,5 \%$ цинка отмечен значительный спад роста ризобий донника до 65 шт. колоний. При этом у колоний ризобий люцерны в данных концентрациях прослеживалась более низкая степень выживаемости, критической стала среда $0,3 \%$ цинка.

Ключевые слова: клубеньковые бактерии; ризобии донника; ризобии люцерны; жизнеспособность колоний; тяжелые металлы; моделирование среды; токсичность среды; ингибирование жизнеспособности; критическая концентрация; токсиканты; цинк; медь; кадмий; свинец; окультуривание техногенно-загрязненных почв.

\section{Введение}

В настоящее время, в связи с возрастающим поступлением тяжелых металлов в почвенный покров значительных территорий, особо актуально внедрение безопасных и высокоэффективных технологий рекультивации техногенно-загрязненных почв, включающих использование фитометодов, применение эффективных биопрепаратов, восстановление продуктивности нарушенных земель, мероприятия, регулирующие подвижность опасных веществ [1-4].

Следует отметить, что в данный момент нет четко установленных сведений о возможностях возделывания полевых культур в условиях преобразованных почв с использованием комплексного фито-биосорбционного модуля.
Важным звеном, осуществляющим протекание наиболее значимых почвенных процессов, являются микроорганизмы. Они способствуют поддержанию почвенного плодородия, участвуют в круговороте биогенных элементов, положительно влияют на режим питания возделываемых культур, стимулируют у растений рост, развитие и устойчивость к стрессовым условиям, являются источником дополнительно накапливающегося «биологического» азота в почве за счет связывания молекулярного азота воздуха [5-13].

Способностью фиксировать молекулярный азот обладают клубеньковые бактерии - симбиотические азотфиксирующие микроорганизмы, с помощью которых осуществляется образование клубеньков и связывание соединений азота [14, с. 157-159]. 